\title{
Pathology of fin erosion in goldfish Carassius auratus
}

\author{
Angela D. Sharples*, Clive W. Evans \\ Developmental Biology and Cancer Research Group, School of Biological Sciences, University of Auckland, \\ Private Bag 92019, Auckland, New Zealand
}

\begin{abstract}
This paper describes the pathology of fin erosion in a feral population of goldfish Carassius auratus (L.) exposed to bleached kraft mill effluent in the Waikato River, New Zealand. Acute fin erosion is initially characterised by hyperplasia of the epidermis, loss of the cuticle and of the epidermal microridges, and the rounding and eventual sloughing of the outermost squamous cells. It typically involves an increase in the number of pigment cells, particularly in the marginal zones of the affected fins, thus accounting for the characteristic black edge of eroded fins. A lymphocytic reaction of variable extent and epidermal oedema are also evident in the acute phase of fin erosion as are increased numbers of mucous cells and decreased numbers of alarm cells in the epithelium. The stratum germinativum and basement membrane of an acutely eroded fin are typically thickened. As fin erosion progresses, increased sloughing of the epidermal cells thins the epidermis. Cells in the stratum germinativum become enlarged and vacuolar and may lift from the basement membrane. Dermal oedema and fibrosis develop early in the progression of the disease with the later stages involving loss of the dermis and erosion of the lepidotrichia. Healed erosion is characterised by dermal fibrosis and the presence of a node of thickened lepidotrichia that is largely unsegmented. New fin rays are formed distally, but they are not continuous initially with the old fin ray stumps. Longitudinally oriented lepidotrichia-forming cells are apparent at the distal tip of the node and in foci distal to the nodal area. Melanophores and basophilic fibroblasts are also abundant and surround each area of fin ray deposition during the healing process. Only in the final stages of healing do the fin rays became continuous with the old fin ray stumps at the node, and the newly formed rays acquire segmentation. Fin erosion as described here is a unique and definitive pathological condition which may have potential as a bioindicator for a variety of pollutants including pulp mill effluents.
\end{abstract}

KEY WORDS: Carassius auratus · Goldfish · Fin erosion - Pathology

\section{INTRODUCTION}

Fin erosion is a pathological condition of bony fishes for which there is no known infectious agent. The disease is marked by a necrosis of the distal part of the fin which initially involves the epidermis but which progresses to involve the dermis and fin rays (Mearns \& Sherwood 1974, Sherwood \& Mearns 1977). This necrosis results in an erosion or shortening of the fin which may be so severe as to leave only the stump remaining. Regeneration of moderately eroded fins results in a typical deformation of the fin rays distal to

•E-mail: a.sharples@auckland.ac.nz the erosion front which can assist in the identification of exposure to previous erosive episodes.

In the past there has been considerable confusion about the applicability of the terms fin rot and fin erosion to describe what appear to be similar pathological conditions. We concur with the views of Lindesjöö \& Thulin (1990), who suggest the use of the term fin erosion to describe a particular type of fin damage in which there is no demonstrable microbial involvement. The term fin rot should thus be reserved for fin lesions characteristically associated with the presence of 1 or more species of microorganism (Post 1983).

A preliminary account of the histopathology of fin erosion was reported for Dover sole Microstenus pacificus by Klontz \& Bendele (1973), who described pro- 
gression of the disease from initial fraying of the fins to degeneration of the bony rays. Subsequent observations on winter flounder Pseudopleuronectes americanus by Murchelano (1975) supported this initial description of the disease. Although Murchelano (1975) referred to the condition as fin rot, there appeared to be no indications of associated bacterial, fungal or protozoal infections which accord with the definition of fin erosion as used here. Ziskowski \& Murchelano (1975) examined the prevalence of fin erosion in winter flounder from the New York Bight, USA, and provided early evidence of a correlation of the disease with environmental degradation. Although the aetiology of fin erosion remains uncertain, evidence increasingly points towards an association with environmental pollution (Mearns \& Sherwood 1974, Sindermann 1984, Cross 1985, Lindesjöö \& Thulin 1990, Sharples et al. 1994). We now describe the pathology of fin erosion in a feral population of goldfish Carassius auratus (L.) exposed to bleached kraft mill effluent in the Waikato River, New Zealand, and discuss the utility of fin erosion as a biomarker for aquatic pollution.

\section{MATERIALS AND METHODS}

Goldfish were captured from 5 sites in the Waikato River located in the North Island of New Zealand
(Sharples et al, 1994). Of these sites, 4 were downstream of a kraft pulp and paper mill which discharges into the Waikato River system. Just prior to the sampling period the mill concerned altered its chlorinebased bleaching process to an oxygen delignification sequence $\left(O D E_{0} D\right)$. The fifth (reference) site included in this study was located $14 \mathrm{~km}$ upstream of the mill discharge.

A minimum of 12 fish were captured from each of the 5 sites in triple hoop fyke nets set for $24 \mathrm{~h}$ periods. On recovery of the nets the fish were immediately transferred to large, water-filled plastic bags for transport to the laboratory where the upper part of the caudal fin and the right pectoral fin were dissected and fixed in 10\% neutral-buffered formalin $(24 \mathrm{~h})$. Fins were then divided into proximal and distal sections, embedded in paraffin blocks, sectioned (5 $\mu \mathrm{m})$ following surface decalcification with von Ebner's solution and stained with Mallory-Heidenhain $(\mathrm{MH})$, haematoxylin \& eosin (H\&E), periodic acidSchiff (PAS), or Gram according to established protocols (Humason 1972). Fins to be examined by scanning electron microscopy (SEM) were fixed in $2.5 \%$ glutaraldehyde in $0.1 \mathrm{M}$ cacodylate buffer for $2 \mathrm{~h}$ at room temperature, dehydrated in ethanol, criticalpoint dried, sputter coated with gold $(20 \mathrm{~nm})$, and viewed in a Philips 501 scanning electron microscope operating at $10 \mathrm{kV}$.

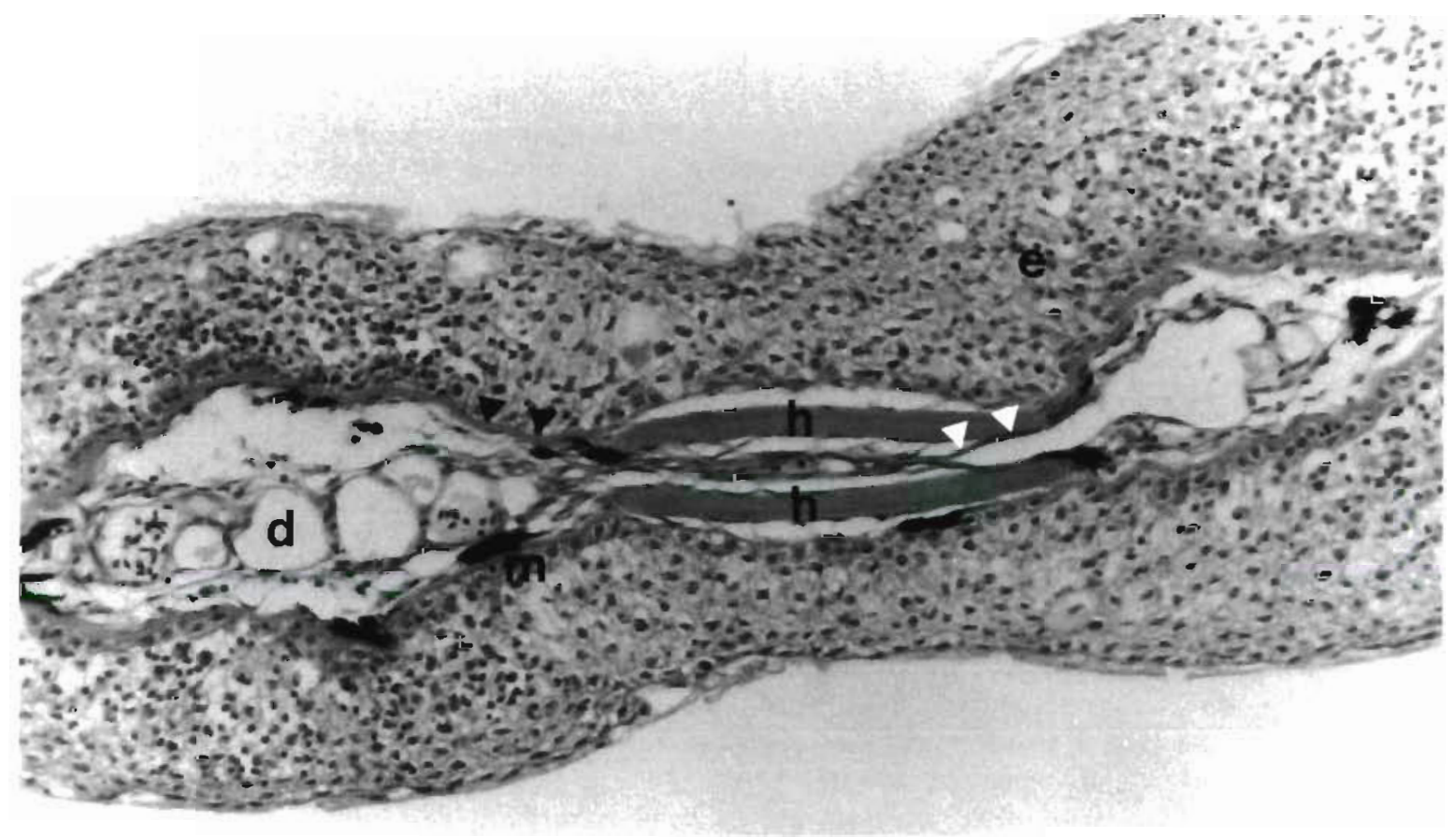

Fig. 1. Carassius auratus. Cross section of the caudal fin of goldfish, $H \& E_{1} \times 250$. Normal fin with a pair of hemisegments (h), dermis (d), epidermis (e) and moderately abundant melanophores (m). Intralepidotrichial (white arrowheads) and interlepidotrichial (black arrowheads) ligaments are clearly visible. Note the desquamation of individual cells in the outermost layer and the presence of cuticle remnants 


\section{RESULTS}

\section{Structure of the normal fin}

The histological appearances of the fins of several teleosts including the goldfish have been described in detail by Lanzing (1976), Becerra et al. (1983) and Brandstätter et al. (1990). Salient features of their reports together with observations of material collected in this study form the basis of this description of the normal goldfish fin. The fins of the goldfish, like those of other teleosts, are supported by more or less parallel skeletal structures of dermal origin (the fin rays or lepidotrichia) which are typically calcified and which branch towards the distal margin of each fin. The lepidotrichia are segmented along their length with segments joined to one another by ligaments at the intersegmental joints. Each lepidotrichium is composed of paired, slightly curved elements (hemisegments) between which lies the intrasegmental region with its nerves, blood vessels and loose connective tissue (Fig. 1). In addition to the intersegmental joints, the hemisegments are held in place by lepidotrichial and tissular ligaments. The intralepidotrichial ligaments extend through the intrasegmental region while the interlepidotrichial ligaments link neighbouring fin rays. The tissular ligaments extend from the outer convex surfaces of some hemisegments into the surrounding connective tissue. Inserted between the hemisegments of the lepidotrichia at their tip are the hair-like, collagenous actinotrichia. These complex arrangements of bony elements and associated ligaments are embedded in loose dermal connective tissue (stratum spongiosum) containing moderately abundant melanophores. The stratum compactum is greatly reduced. The dermis is bounded on both sides by a stratified squamous epithelium completely investing the fin and continuous with the epidermis of the body. The stratum germinativum of the fin is a single basal layer of columnar cells with large, pale, and uniformly oval nuclei. The bases of these cells are strongly folded and separated from the dermis by a basement membrane which closely follows the wavy profile of the proximal epidermal cells, a feature described in Tilapia mossambica by Lanzing (1976). The basement membrane is generally thicker in the interlepidotrichial region than it is adjacent to the hemisegments. In contrast to those in the stratum germinativum, the nuclei of the remainder of the epidermis are densely staining and irregularly shaped. In addition to the epithelial cells, abundant mucous cells, club cells (see Fig. 6), and nerve end organs are found in the epidermis. Mucous cells and nerve end organs are concentrated at the tip of the fin whereas club cells are most abundant in the proximal regions of the fin.
The superficial cells of the epidermis are squamate and the external surface of each forms a series of folds (epidermal microridges or papillae) resembling fingerprints, a feature first described by Merrilees (1974) and Hawkes (1974). An overlying cuticle is present although it is frequently damaged by routine tissueprocessing techniques.

\section{Pathology of fin erosion}

Fin erosion is a dynamic process that can alternate with periods of healing and regeneration or progress to an extent where regeneration is no longer possible. The following description represents a summary of the major events apparent in the process of fin erosion and is based on the interpretation of both histological and SEM preparations.

Pathologically, the initial phase of acute fin erosion is marked by loss of the cuticle and necrosis and sloughing of the squamous epidermal cells (Fig. 2). SEM reveals a number of surface changes associated with acute fin erosion, with the initial erosive changes expressed proximally and the more extensive advanced pathology expressed distally at the tip of an eroded fin (Fig. 3A). Normal epidermal cells clearly show epidermal microridges under SEM (Fig. 3B) which are lost in the early stages of fin erosion $(3 C)$. The outermost epidermal cells then round up (3D) and slough off. As erosion progresses necrosis affects a variable thickness of epidermal cells and the epidermis becomes oedematous. An epidermal lymphocytic reaction of variable extent is apparent and epidermal haemorrhage may also be observed but neither of these processes is extensive. A moderate lymphocytic infiltration of the fin epidermis was recorded in one control fish without overt signs of fin erosion. The stratum germinativum is typically hyperplastic, with cells in this layer being increasingly columnar compared with normal fins. This phase of acute erosion is also notable for a thickened hyperplastic epithelium at the tip of the fin which is clearly visible under SEM. Melanophores are abundant, accounting for the characteristic black edge of acutely eroding fins (Fig. 4). In these early stages of acute fin erosion the basement membrane is thickened forming complex interdigitations with the basal epithelial cells. Mucous cells are more abundant in the epidermis of the acutely eroded fin (particularly in the distal regions of the fin) than in the normal fin, and mucus strands are clearly visible under SEM, even on wellwashed specimens. Alarm cells are less common in acutely eroded fins. Occasional dead cells recognised by pyknosis or karyorrhexis are also apparent within the epidermis. 


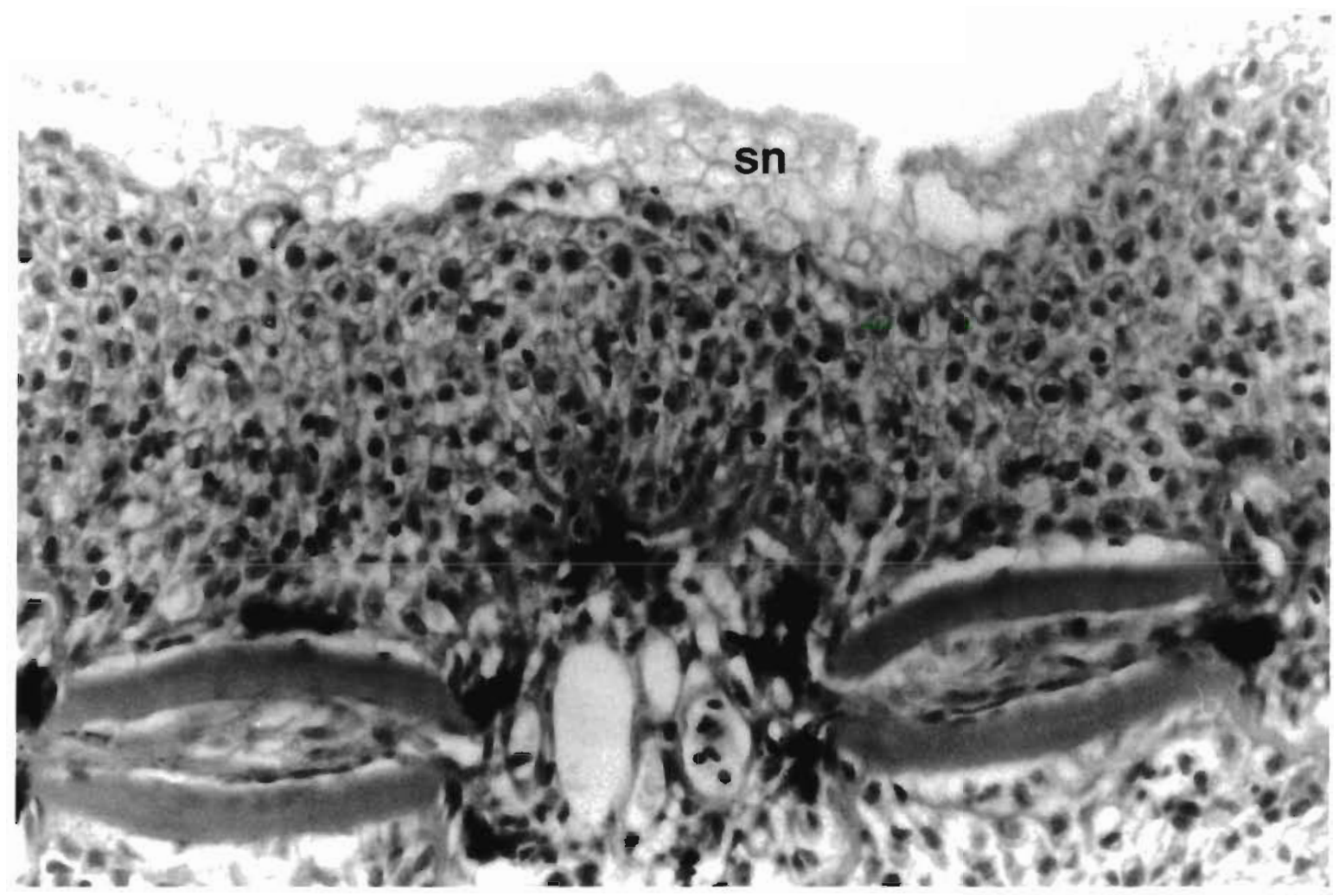

Fig. 2. Carassius auratus. Cross section of the caudal fin of goldfish, $H \& E, \times 500$. Early acute erosion with surface necrosis (sn) and loss of the outermost squamous epidermal cells

More advanced stages of fin erosion are characterised by progressive thinning of the epidermis due to increased sloughing of the epidermal cells. The cells in the stratum germinativum become enlarged and vacuolar and lift from the underlying basement membrane (Fig. 5). This progressive loss of the epidermal cells resulting in the exposure of the basement membrane is clearly apparent under SEM (Fig. 3E). Partial loss of the basement membrane in the distal regions of the fin, dermal oedema and fibrosis (Fig. 6) are common. Osteoclasts aggregate at the eroding tip of the lepodotrichia and can be seen lying in pockets within the fin ray. The lepidotrichia have a 'sponge-like' appearance, with more intense basophilic staining (Fig. 7). In severe erosion, loss of the basement membrane is seen in the distal region of the fin and there is marked dermal oedema followed by complete loss of the lepidotrichia and dermis resulting in the characteristic shortening or erosion of the fin. Bacteria were observed in only 2 acutely eroded fins suggesting that their appearance was probably a secondary-related event. Fungal infections were not observed.

\section{The healed fin}

The healed phase of fin erosion was also observed histologically. The line of healed erosion visible macroscopically consists of a proximal node of thickened lepidotrichia which is largely unsegmented and associated with dense fibrous tissue. These 2 features, the lepidotrichial node and dermal fibrosis, are characteristic of healed fin erosion. New fin rays are deposited at the distal tip of the eroded fin, apparently by a process

Fig. 3. Carassius auratus. (A) Caudal fin of goldfish with acute erosion (SEM). Note the progressive loss of the epithelium and exposure of the lepidotrichia (l) at the distal tip of the fin. Segmentation of the lepidotrichia is apparent (white arrowheads) beneath the partially lost basement membrane. Scale bar $=500 \mu \mathrm{m}$. (B) Epidermal microridges, normal pectoral fin of goldfish (SEM). Scale bar $=5 \mu \mathrm{m}$. (C) Detail of the loss of epidermal micronidges in early acute erosion, caudal fin of goldfish (SEM). Scale bar $=5 \mu \mathrm{m}$. (D) Detail of the rounding and loss of the outermost epidermal cells in early acute erosion, caudal fin of goldfish (SEM). Scale bar $=10 \mu \mathrm{m}$. (E) Progressive loss of the epidermis (e) and exposure of the underlying basement membrane (bm) in early acute erosion, caudal fin of goldfish (SEM). Scale bar $=100 \mu \mathrm{m}$ 


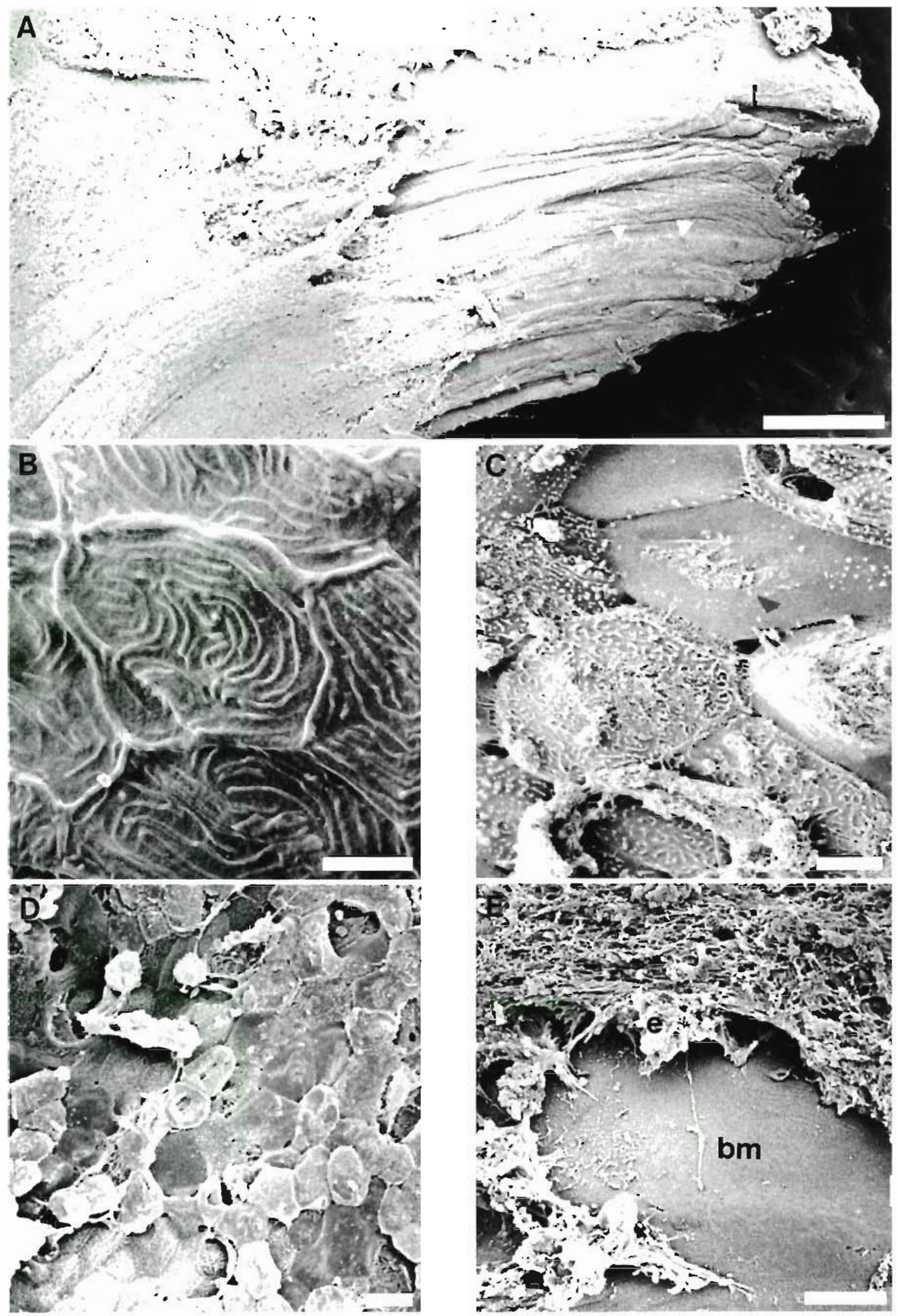




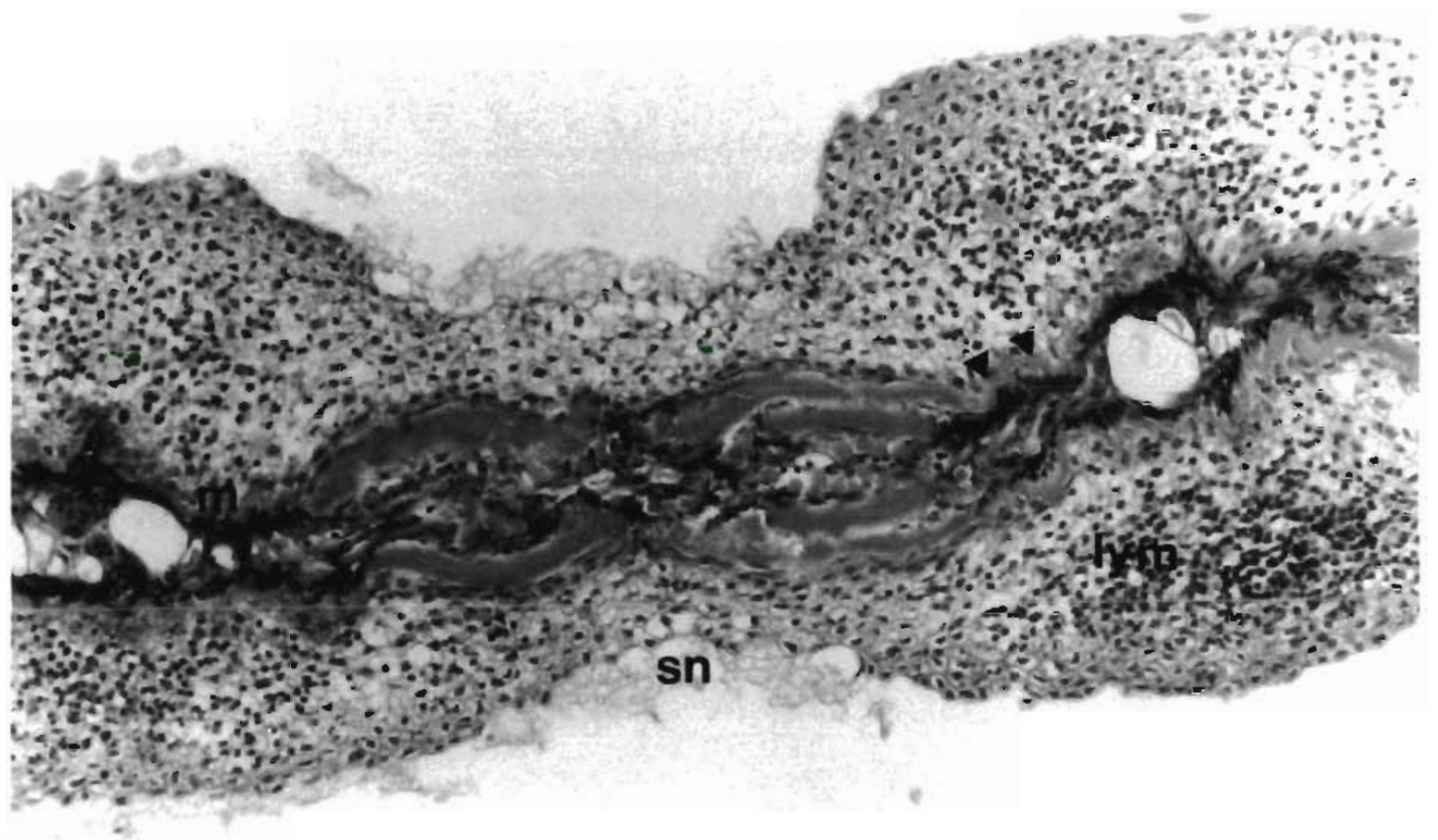

Fig. 4. Carassius auratus. Cross section of the caudal fin of goldfish, $\mathrm{H} \& \mathrm{E}, \times 250$. Acute erosion with surface necrosis (sn) affecting a variable thickness of the epidermis. A lymphocytic infiltrate (lym) is seen within the epidermis, and a thickened basement membrane (arrowheads) and abundant melanophores $(\mathrm{m})$ are also present. Note the lack of outermost squamous epithelial cells

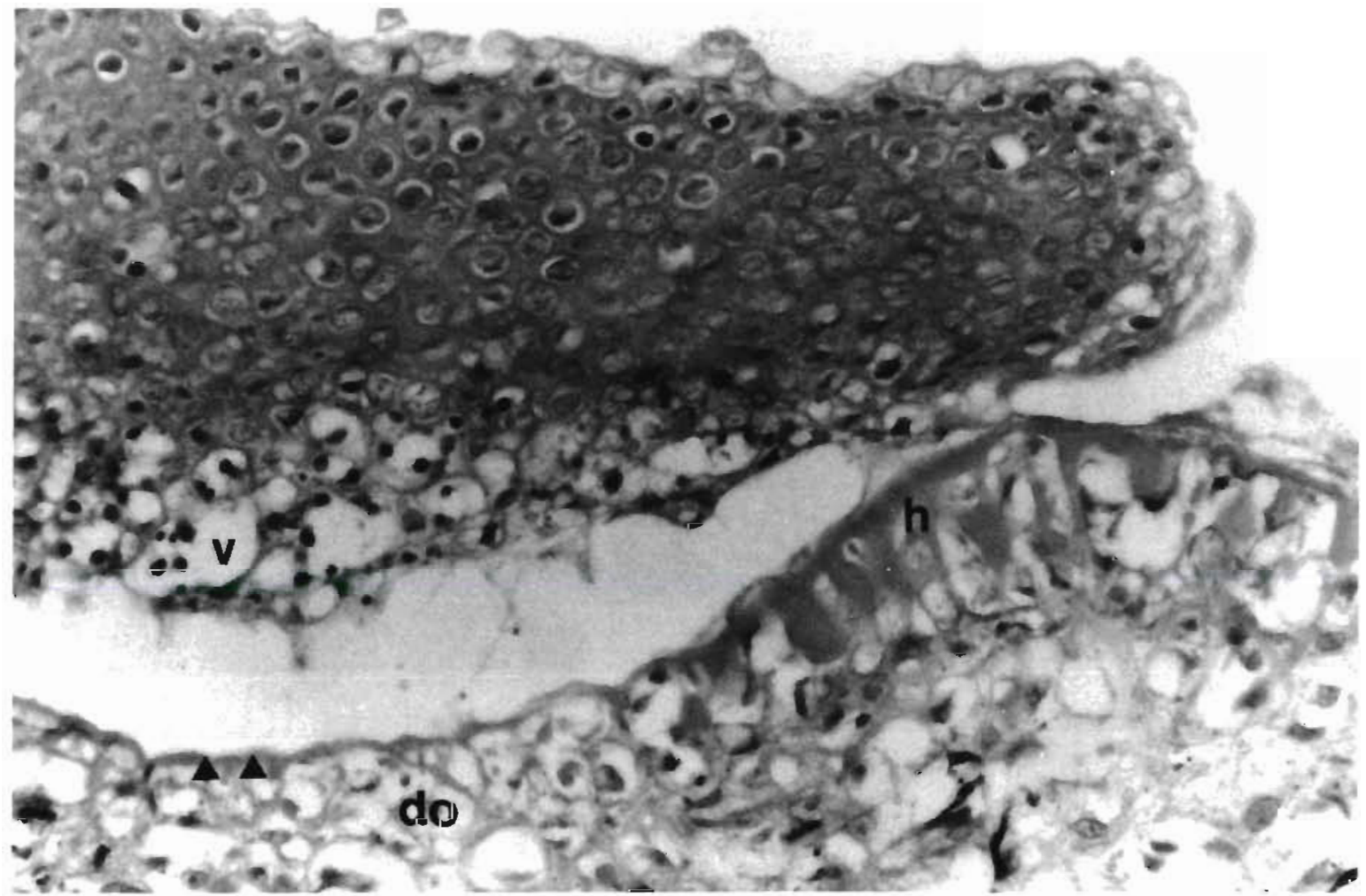

Fig. 5. Carassius auratus. Cross section of the caudal fin of goldfish, $\mathrm{H} \& \mathrm{E}, \times 500$. Acute erosion with vacuolation of the stratum germinativum (v), lifting of the epidermis (arrowheads), dermal oedema (do), and partial erosion of a lepidotrichial hemisegment (h) 


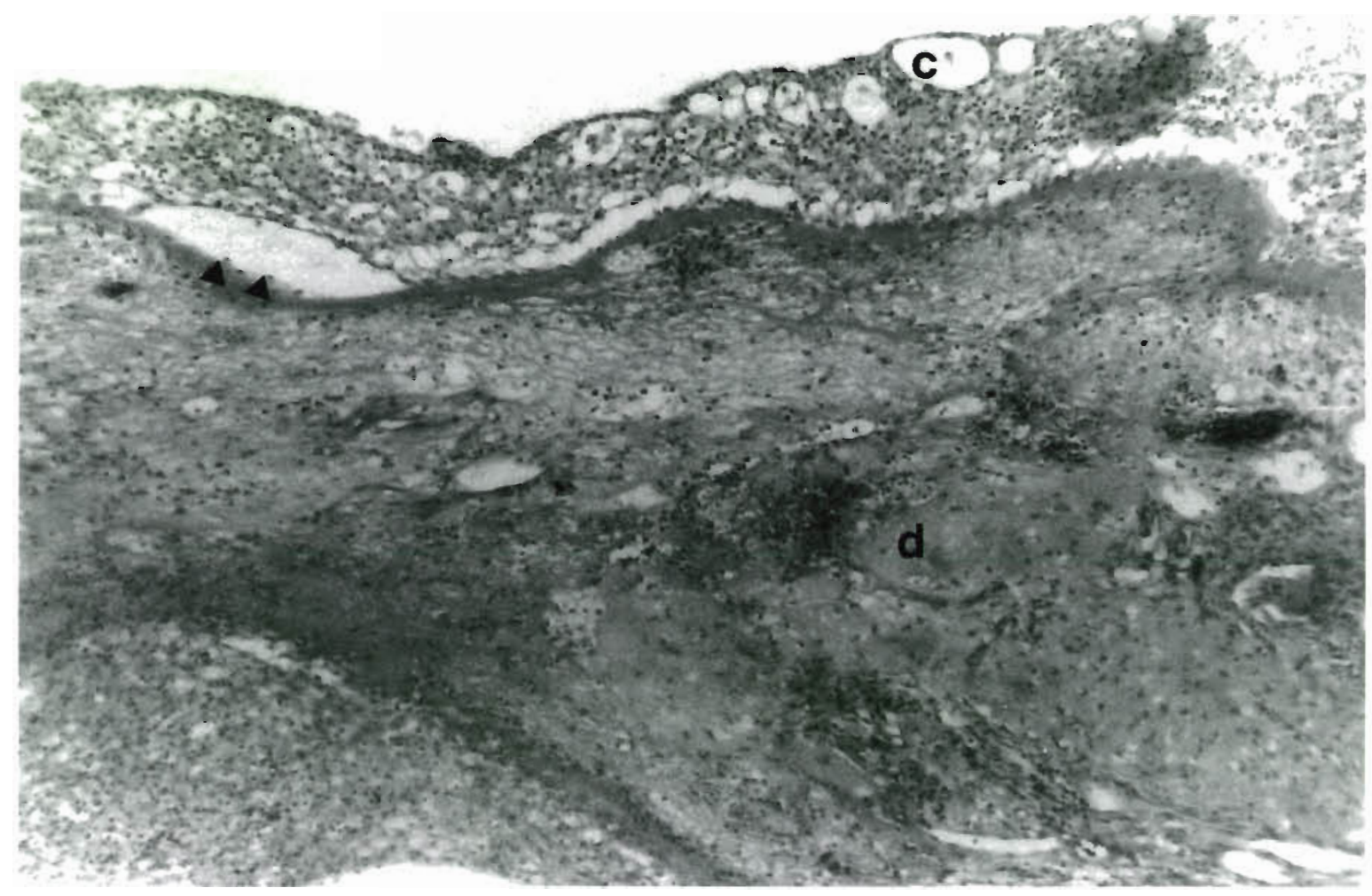

Fig. 6. Carassius auratus. Cross section of the pectoral fin of goldfish, $H \& E, \times 125$. Acute erosion with extensive fibrosis of the dermis (d) and lifting of the epidermis (arrowheads). Note club cells (c) in the epidermis of this proximal section

of addition analogous to that occurring in normal growth of the fin. However, these new distal fin rays are initially not continuous with the old fin ray stumps. Deposition of new lepidotrichia and remodelling of existing lepidotrichia occurs in the region immediately distal to the lepidotrichial node even in fins that are apparently completely healed when viewed macroscopically. Tissue healing and remodelling is therefore slower adjacent to the node.

The distal tip of the lepidotrichial node is associated with continued deposition of new fin rays and deposition is also observed in foci immediately distal to the tip of the node. The stratum germinativum is less well developed adjacent to the lepidotrichial node but is prominent and active distal to the node where active deposition of the lepidotrichia remains apparent. Melanophores are particularly abundant in the dermis of this region, surrounding the tip of the node and the foci of tissue where active lepidotrichial deposition is occurring. Blood vessels are also prominent in the dermis of this area. Fibroblasts adjacent to the area of deposition are abundant and appeared more basophilic. A single layer of lepidotrichia-forming cells (ovoid, pale-staining cells with poorly differentiated cytoplasm) could be seen surrounding the areas of lepidotrichial deposition. Each cell is oriented longitudinally (Fig. 8). The first collagen fibres of the regenerat- ing lepidotrichium to be laid down (observed at the tip of the healing fin ray) were transversely arranged. The development of an orthogonal array involving the longitudinal deposition of collagen fibres followed later as did the acquisition of the characteristic lepidotrichial segmentation and ligament arrangement. The epidermis is apparently normal except for the features of the stratum germinativum that were described above and the variable occurrence of slight hyperplasia adjacent to the node. There is no oedema, fibrosis, or excessive sloughing such as is characteristic of acute erosion. A cuticle is present.

Under SEM, healed fin erosion is marked by a faint thickening, corresponding to the node of thickened lepidotrichia. This is largely masked by the epidermis lying above and is not always obvious. Macroscopic observation of the fin against a strong light source or against a white background is therefore more definitive than SEM for the identification of healed erosion.

\section{DISCUSSION}

The pathology of acute fin erosion is summarised in Fig. 9. It is initially characterised by hyperplasia of the epidermis and loss of the cuticle and epidermal micro- 


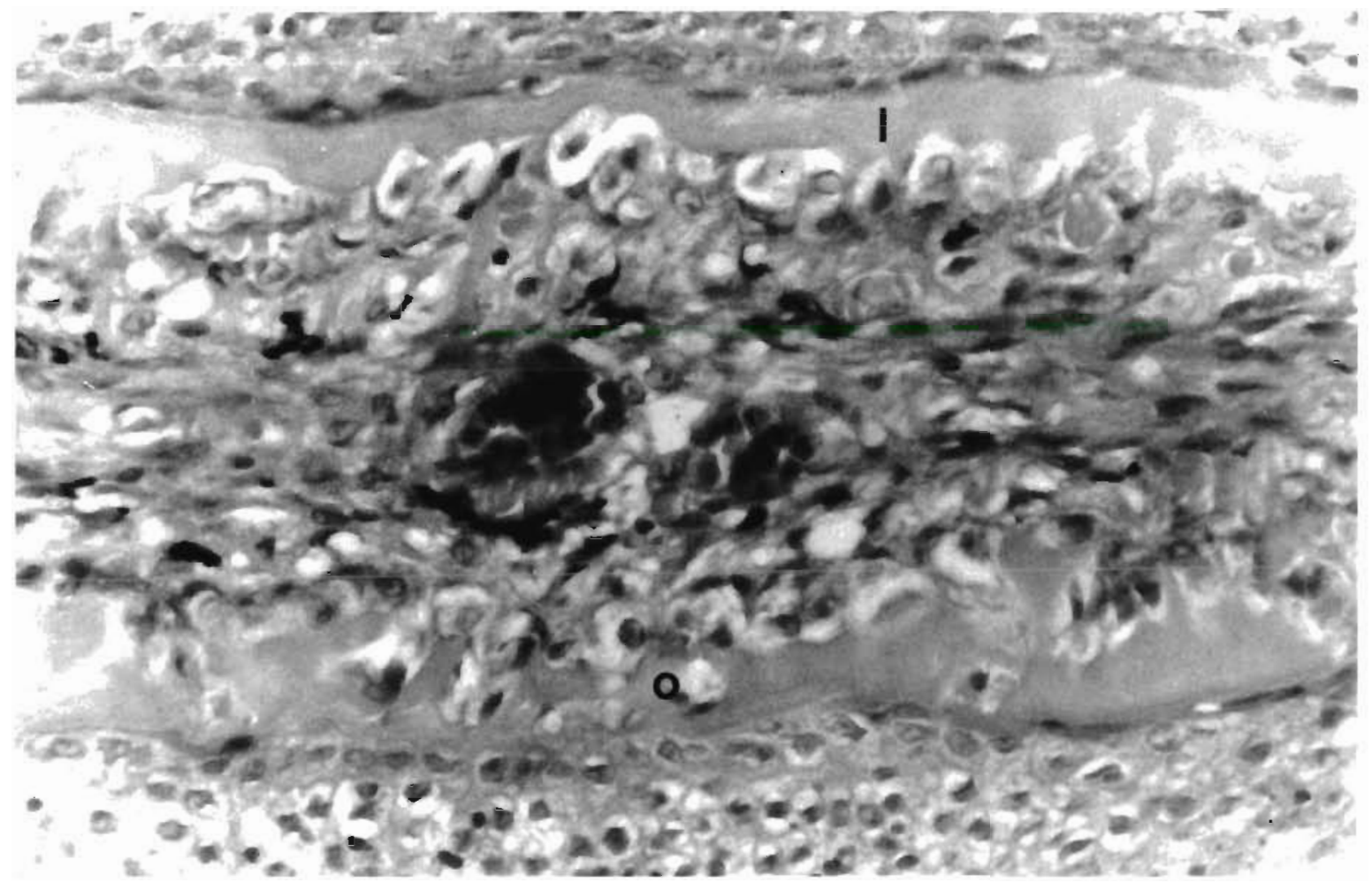

Fig. 7. Carassius auratus. Cross section of the caudal fin of goldfish, H\&E, $\times 500$. Acute erosion of the lepidotrichia (l). Note osteoclasts (o) contained in pockets in the partially eroded hemisegments

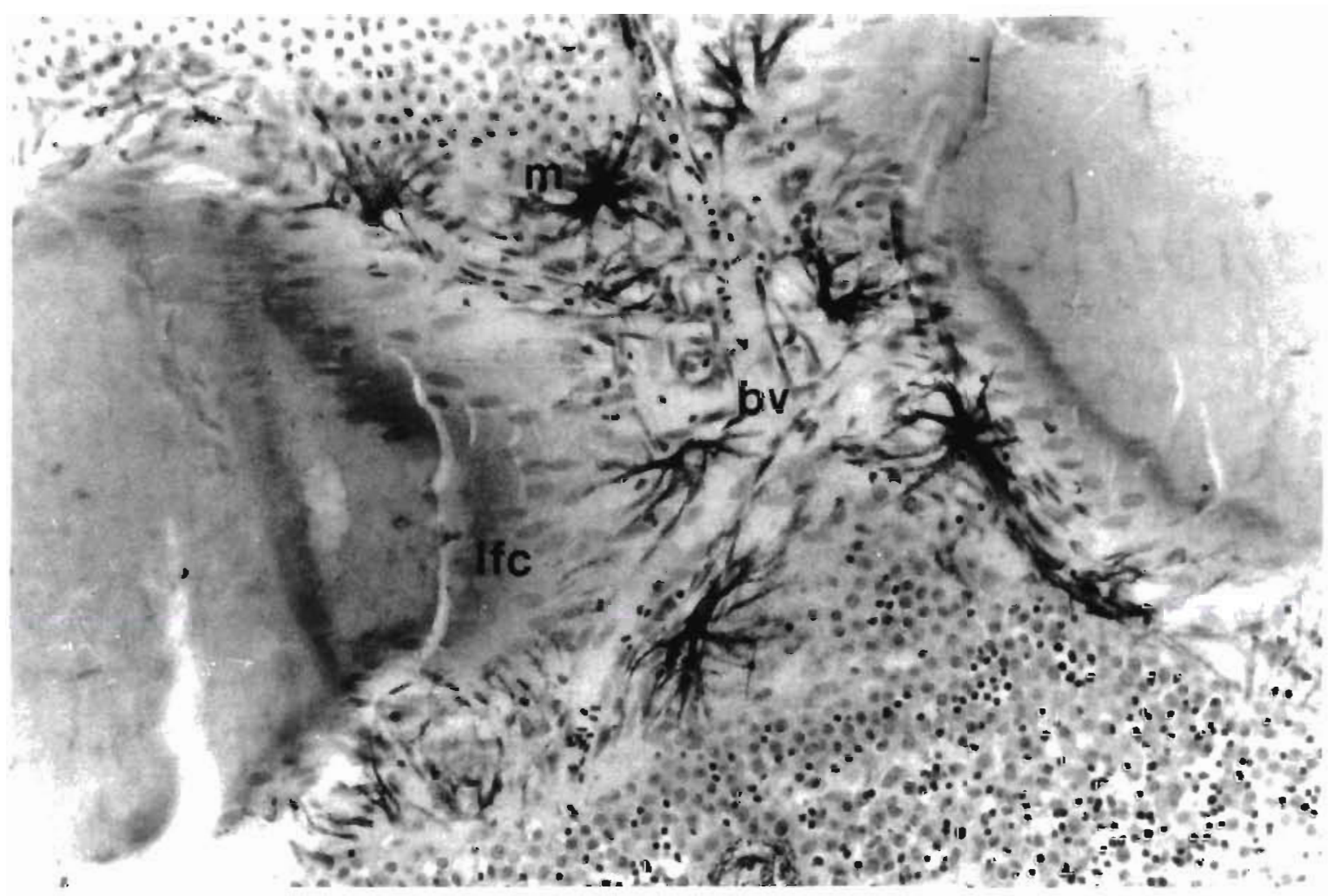

Fig. 8. Carassius auratus. Longitudinal section of the caudal fin of goldfish, $H \& E_{1} \times 250$. Detail of an area of active lepidotrichial deposition in the healed fin. Longitudinally oriented lepidotrichia-forming cells (lfc) are apparent and blood vessels (bv) and melanophores $(m)$ are common. Note the lack of a distinct basement membrane 


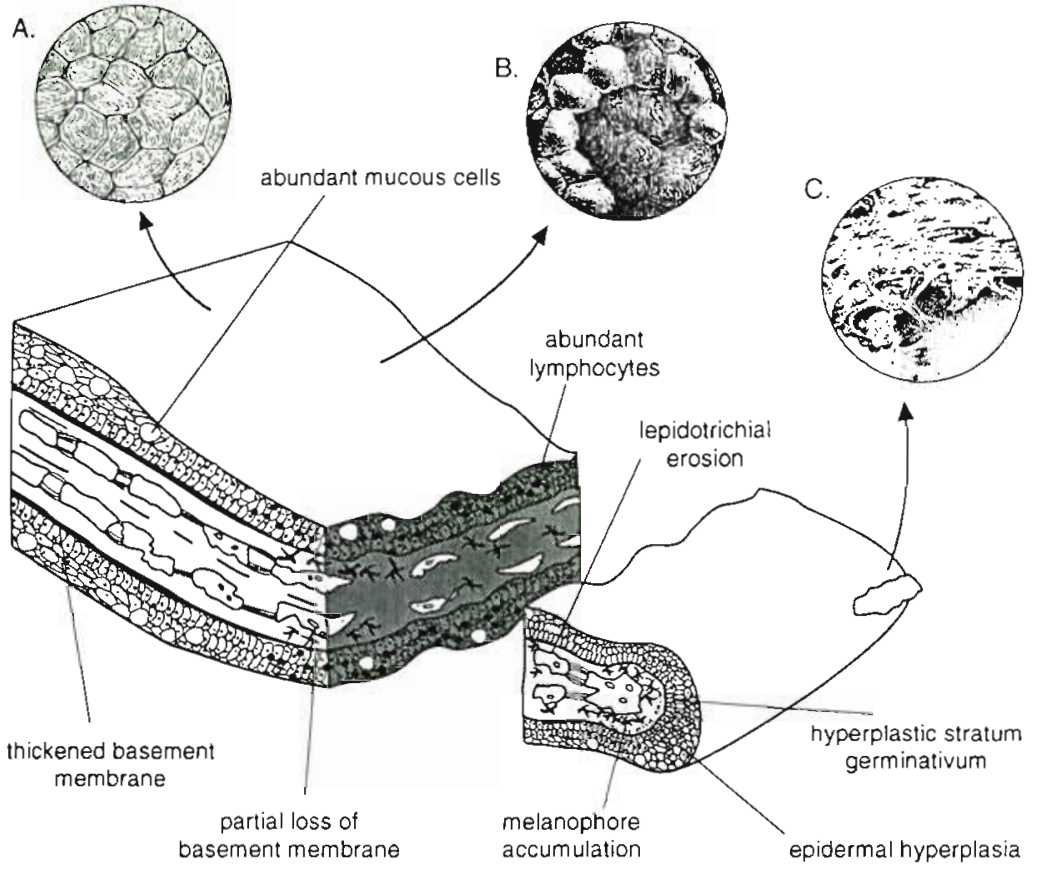

Fig. 9. Carassius auratus. Three-dimensional diagrammatic representation of the main features of acute fin erosion in goldfish. (A) Normal squamous epidermal cells with surface microridges. (B) Loss of the cuticle and epidermal microridges and rounding and sloughing of outermost epidermal cells. (C) Erosion of the epidermis resulting in exposure of the basement membrane and the fin rays

ridges followed by the rounding and eventual sloughing of the outermost squamous cells. Our observations do not allow us to comment on the aetiology of these changes although we can confirm that they are independent of obvious microbial involvement. Epidermal hyperplasia has been a common finding of previous histological studies of fin erosion in fish collected from polluted environments (Wellings et al. 1977, Murchelano \& Ziskowski 1982, Lindesjöö \& Thulin 1994). The sloughing of epithelial cells observed involved sheets of cells several layers thick (Fig. 2). This can be contrasted with the less extensive desquamation of the outermost epithelial cells seen in the normal fin (Fig. 1), which is part of the normal process of epithelial cell turnover. Fin erosion typically involved an increase in the number of pigment cells, particularly in the marginal zones of the affected fins. This accounted for the black edge of eroded fins, which has also been a frequent finding of studies in the past (Murchelano 1975, Lindesjöö \& Thulin 1994). A lymphocytic reaction of variable extent and epidermal oedema were characteristic of the acute phase of fin erosion as were increased numbers of mucous cells and decreased numbers of alarm cells in the epithelium.

It is thought that the susceptibility of the teleost skin to damage is influenced by such physical properties as epidermal thickness and mucus production. Mork et al.
(1989), who showed that mature male Atlantic salmon Salmo salar exhibited consistently lower prevalences of fin erosion than immature males, related this observation to skin thickening and increased mucus production associated with maturation. Both skin thickening and increased mucus production are known to be under hormonal control (Pottinger \& Pickering 1985) and may perhaps be modulated by stress (Fletcher 1981). The influence of stress in the aetiology of fin erosion, however, remains speculative.

The stratum germinativum of an eroded fin is typically thickened as is the basement membrane, which can become highly folded. As erosion progresses sloughing of the epidermal cells thins the epidermis. Cells in the stratum germinativum become enlarged and vacuolar and may lift from the basement membrane, and dermal oedema and fibrosis become apparent. Progressive loss of the dermis follows and osteoclasts lying within pockets in the lepidotrichia are active in the concomitant erosion of the lepidotrichia.

Healed erosion (Fig. 10) was characterised by dermal fibrosis and the presence of a node of thickened lepidotrichia that is largely unsegmented, a feature

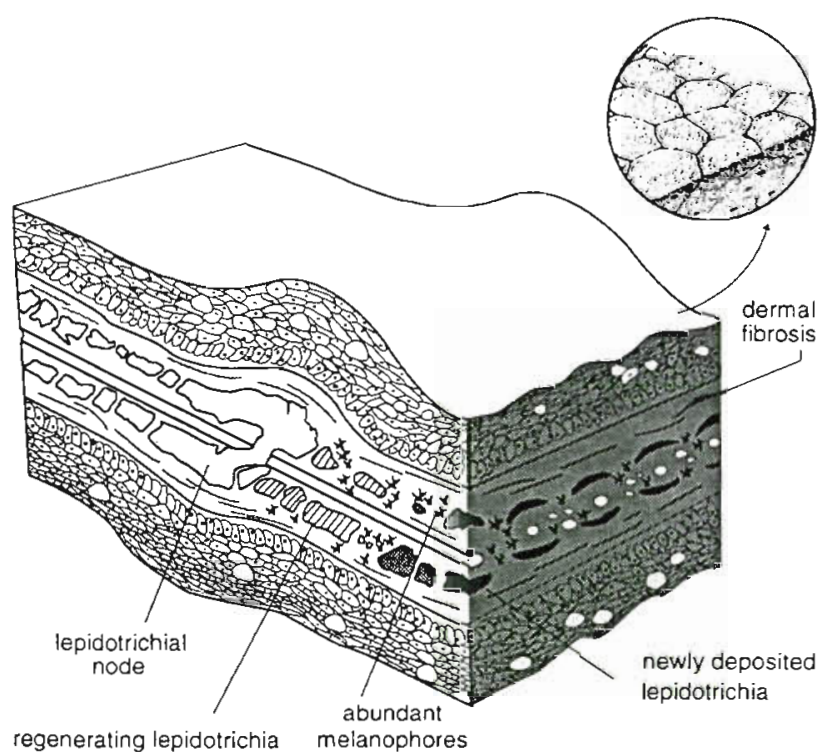

Fig. 10. Carassius auratus. Three-dimensional diagrammatic representation of the main features of healed fin erosion in goldfish. Insert shows detail of normal squamous epidermal cells with surface microridges 
commented on by Becerra et al. (1983). The new fin rays distal to the node were apparently Iaid down by the normal process of fin ray growth and were not initially continuous with the old fin ray stumps. The distal tip of the node was associated with the continued deposition of new fin rays by longitudinally oriented lepidotrichia-forming cells. Deposition of new fin rays was also observed at the proximal edge of the distal fin rays and in foci of deposition between the fin ray stump and the new distal fin rays. Melanophores were abundant and surrounded each area of fin ray deposition. Fibroblasts were also abundant and showed enhanced basophilia. The collagenous component of the lepidotrichia was laid down first transversely and then longitudinally in agreement with the sequence of lepidotrichial development first suggested by Prenant (1936). This also agrees with the arrangement of collagen in the lepidotrichia of adult teleosts reported by Becerra et al. (1983). Calcification followed collagen deposition. In the final stages of healing, the fin rays became continuous with the old fin ray stumps at the node and the newly formed rays progressively acquired segmentation

The sequence of events involved in fin healing as summarised above shows many similarities with experimental observations of regenerating tail fins (Goss 1969, Santamaría \& Becerra 1991). Experimental fin amputation is quickly followed by wound healing and blastema formation. However, the situation during fin erosion appears more complex, largely because fin erosion is a chronic process in which elements of erosion and healing can occur simultaneously. This, taken together with the temporary nature of the blastema itself, presumably accounts for the absence of a distinct blastema in the fins of the field population of goldfish examined in this study.

Fin erosion as described here is a unique and definitive pathological condition. Acute erosion is readily distinguishable from injuries sustained during capture, having a number of diagnostic features including epidermal hyperplasia, a thickened basement membrane, and mucous cell and melanophore accumulation. Fin erosion, although sharing many features with fin rot, is distinct from the latter in that it is not associated with any microbiological infections other than as occasional secondary events. Healed fin erosion presents a line of thickened lepidotrichial nodes which are diagnostic of previous erosive episodes, but at this stage the persistence of these nodes remains uncertain. It is conceivable that lepidotrichial remodelling ultimately leads to replacement of the nodes with normal lepidotrichial tissue thus removing any traces of a previous erosive episode.

Chemicals within the environment have been proposed as contributory factors in the development of fin erosion and a number of studies have suggested a correlation between the presence of pollutants and the prevalence of fin erosion (Mearns \& Sherwood 1974 Sherwood \& Mearns 1977, Cross 1985, Lindesjöö \& Thulin 1990). Indeed a previous paper by the present authors showed that fin erosion in the goldfish which are the subject of this study was clearly correlated with the effluent gradient from a pulp and paper mill (Sharples et al. 1994). Fin erosion was also found to occur most commonly on the pectoral (56\%) and caudal fins $(33 \%)$, which are the main locomotory fins of the goldfish. Fin erosion appears to have great potential as a bio-indicator for a variety of pollutants including pulp mill effluents. Further refinement of diagnostic methods and additional correlative field and laboratory studies of fin erosion with the presence of pollutants should clarify the potential of fin erosion as an indicator of environmental pollution.

Acknowledgements. Financial support for this study was provided by New Zealand Forest Products, Pulp and Paper Ltd and the Auckland University Research Committee. The authors are grateful to Beryl Davies, Raewyn Eagar, Iain MacDonald, Jenny Rains and Vivian Ward for their technical support and to Dr Jan Thulin (Institute of Marine Research. Lysekil, Sweden) for his advice and encouragement.

\section{LITERATURE CITED}

Becerra J, Montes MS, Bexiga SRR, Junqueira LCU (1983) Structure of the tail fin in teleosts. Cell Tissue Res 230: $127-137$

Brandstätter R, Misof B, Pazmandi C, Wagner GP (1990) Micro-anatomy of the pectoral fin in blennies (Blennini, Blennioidea, Teleostei). J Fish Biol 37:729-743

Cross JN (1985) Fin erosion among fishes collected near a southern California municipal wastewater outfall (1971-1982). Fish Bull US 83:195-206

Fletcher TC (1981) Non-antibody molecules and the defence mechanisms of fish. In: Pickering AD (ed) Stress and fish Academic Press, London, p 171-179

Goss RJ (1969) Principles of regeneration. Academic Press New York

Hawkes JW (1974) The structure of fish skin. I. General organization. Cell Tissue Res 149:147-158

Humason GL (1972) Animal tissue techniques, 3rd edn. WH Freeman \& Company, San Francisco

Klontz GW, Bendele RA (1973) Histopathological analysis of fin erosion in Southern California marine fishes. Rep TM 203. Southern California Coastal Research Project, El Segundo

Lanzing WJR (1976) The fine structure of fins and finrays of Tilapia mossambica (Peters). Cell Tissue Res 173:349-356

Lindesjöö E, Thulin J (1990) Fin erosion of perch Perca fluviatilis and ruffe Gymnocephalus cernua in a pulp mill effluent. Dis aquat Org 8:119-126

Lindesjöö E, Thulin J (1994) Histopathology of skin and gills of fish in pulp mill effluents. Dis aquat Org 18:81-93

Mearns AJ, Sherwood MJ (1974) Environmental aspects of fin erosion and tumors in southern California Dover sole. Trans Am Fish Soc 103:799-810 
Merrilees MJ (1974). Epidermal fine structure of the teleost Esox americanus (Esocidae, Salmoniformes). J ultrastruct Res 47:272-283

Mork J, Jarvi T, Hansen PP (1989) Lower prevalence of fin erosion in mature than in immature Atlantic salmon (Salmo salar) parr. Aquaculture 80:223-229

Murchelano RA (1975) The histopathology of fin rot disease in winter flounder from the New York Bight. J Wildl Dis 11:263-267

Murchelano RA, Ziskowski $J$ (1982) Fin rot disease in the New York Bight (1973-1977). In: Myer GF (ed) Ecological stress and the New York Bight: science and management. Estuarine Research Foundation, Columbia, p 347-358

Post GW (1983) Textbook of fish health. TFH Publications Inc. Ltd, Neptune City

Pottinger TG, Pickering AD (1985) Changes in skin structure associated with elevated androgen levels in maturing brown trout, Salmo trutta L. J Fish Biol 26:745-753

Prenant $M$ (1936) Structure fine et croissance normale des

Responsible Subject Editor: L. B. Schreck, Corvallis, Oregon, USA lépidotrichies articulés chez les téléostéens. C r Séances Soc Biol 123:474-475

Santamaría JA, Becerra J (1991) Tail fin regeneration in teleosts: cell-extracellular matrix interaction in blastemal differentiation. J Anat 176:9-21

Sharples AD, Campin D. Evans CW (1994) Fin erosion in a feral population of goldfish (Carassius auratus, L.) exposed to bleached kraft mill effluent. J Fish Dis 17 . $483-493$

Sherwood MJ, Mearns AJ (1977) Environmental significance of fin erosion in southern California demersal fishes. Ann NY Acad Sci 298:177-189

Sindermann CJ (1984) Fish and environmental impacts. Arch FischWiss 35:125-160

Wellings SR, Alpers CE, McCain BB, Myers MS (1977) Fish disease in the Bering Sea. Ann NY Acad Sci 298:290-304

Ziskowski J, Murchelano R (1975) Fin erosion in winter flounder (Pseudopleuronectes americanus) from the New York Bight. Mar Pollut Bull 6:26-28

Manuscript first received: December 21, 1994

Revised version accepted: August 4, 1995 